\title{
KOMPETENSI LOKAL DALAM MENANGGULANGI KEMISKINAN DI DAERAH INDUSTRI
}

\author{
Oleh \\ Meilanny Budiarti Santoso.
}

\begin{abstract}
Abstrak
Kemiskinan di daerah industri menarik untuk dikaji karena daerah industri selayaknya menjadi potensi yang akan mendatangkan keuntungan bagi wilayah yang bersangkutan. Namun, pada kenyataannya, banyak daerah industri dengan kondisi masyarakatnya tergolong miskin.

Kecamatan Majalaya merupakan salah satu daerah industri di Jawa Barat yang masyarakatnya sejak abad ke-18 memiliki keterikatan yang sangat erat dengan kegiatan industri sehingga masyarakatnya mempunyai kompetensi lokal yang khas.

Kompetensi lokal yang dimiliki masyarakat Majalaya mestinya menjadi modal yang kuat bagi upaya membangun kehidupan yang sejahtera. Namun faktanya, angka kemiskinan di Kecamatan Majalaya masih tinggi. Hal ini terjadi karena ada banyak faktor yang menyebabkan kurang optimalnya kontribusi kompetensi lokal dalam upaya penanggulangan kemiskinan di Kecamatan Majalaya.

Dalam keberadaannya, kompetensi lokal yang tumbuh dan berkembang di dalam masyarakat tidak bisa dipisahkan dari aspek kondisi geografis, historis, dan sosio-politis. Kompetensi lokal di dalam masyarakat mempunyai keragaman dan mengalami dinamika dari waktu ke waktu; setiap kompetensi lokal mempunyai kompleksitasnya sendiri dan senantiasa terkait dengan potensi wilayah setempat. Jumlah dan kondisi kemiskinan di daerah industri tidak bisa dilepaskan dari laju industrialisasi yang tidak berbasis pada pemberdayaan warga setempat dan kurangnya perhatian pihak-pihak terkait terhadap kompetensi lokal di dalam masyarakat.
\end{abstract}

\section{Kata kunci:}

Kompetensi lokal, kemiskinan, daerah industri, potensi wilayah

\section{A. PENDAhuluan}

Berbicara mengenai upaya penanggulanan kemiskinan, maka sudah seharusnyalah juga membicarakan mengenai kompetensi lokal yang dimiliki oleh masyarakat di daerah yang bersangkutan. Situasi hari ini, ketika berbicara mengenai kemiskinan sering kali melupakan potensi yang dimiliki oleh daerah yang bersangkutan. Padahal ketika orang berkumpul dan membentuk suatu masyarakat, secara otomatis - namun sering kali tidak disadari - mereka akan saling belajar untuk beradaptasi dengan situasi dan kondisi lingkungan serta wilayahnya untuk dapat mempertahankan kelangsungan hidup mereka. Hal inilah yang kemudian akan menjadi cikal bakal terbentuknya kompetensi lokal.

Adapun keberadaan kompetensi lokal di dalam masyarakat sebagai sebuah potensi yang dapat digunakan bahkan dioptimalkan dalam upaya penanggulangan kemiskinan akan selalu dihadapkan pada dua hal, yaitu sebagai sesuatu yang akan dikaitkan dengan konteks yang dapat diterima oleh suatu entitas sosial-profesional atau "pasar", sehingga dapat diacu sebagai ukuran tingkat keahlian dalam bidangnya. Di sisi lainnya terdapat tarikan substansi (kebudayaan) yang kompleks, sebagai suatu jalinan multisektor, multidimensi, dan dinamis. 
Sejalan dengan hal tersebut, pembangunan wilayah yang dilakukan oleh pemerintah serta stakeholders lainnya sudah seharusnya bertumpu pada sumberdaya dan kompetensi lokal yang dimiliki oleh wilayah yang bersangkutan. Sayangnya di tengahtengah era otonomi daerah ini, hal tersebut belum dapat terealisasi, karena pembangunan yang dilakukan masih seragam ataupun berbasis pada program yang corak dan ragamnya terkesan saling tiru atau imitasi. Idealnya, sumberdaya dan potensi yang dimiliki oleh suatu wilayah harus selaras dalam optimalisasinya dengan program pembangunan, yaitu melalui pengembangan kompetensi lokal yang ada di tengah-tengah masyarakat melalui proses interaksi dan proses pembelajaran sosial di dalam masyarakat.

Sejumlah variabel dapat dipakai untuk mengkaji kemiskinan, begitupun pada konteks kemiskinan di daerah industri. Berbagai variabel kemiskinan seperti antara lain: pendidikan, kesehatan, ekonomi, kultur, dan struktur diharapkan dapat dihasilkan strategi dan kebijakan pengentasan kemiskinan yang diharapkan dapat tepat sasaran dan berkesinambungan.

Secara umum, pendidikan dan mutu kesehatan yang rendah dipandang sebagai penyebab kemiskinan. Khusus pada masyarakat di daerah industri, kepemilikan alat-alat produksi yang terbatas dan penguasaan teknologi yang kurang dipandang sebagai penyebab munculnya kelambanan dalam proses produksi sehingga menyebabkan masyarakat kurang bisa bersaing dengan para pelaku industri lainnya dan pada akhirnya melanggengkan kemiskinan. Demikian pun dengan faktor kultur dan struktur juga kerap dilihat sebagai elemen penting yang menentukan tingkat kesejahteraan masyarakat.

Kemiskinan merupakan persoalan
yang
kompleks. Karena itu, cara penanggulangannya pun membutuhkan analisis yang tepat, melibatkan semua komponen termasuk masyarakat miskin itu sendiri serta diperlukan strategi penanganan yang tepat, berkelanjutan, dan tidak bersifat temporer. Namun, apabila dicermati, upaya pengentasan kemiskinan yang dilakukan selama ini, antara lain melalui penyediaan kebutuhan dasar seperti pangan, pelayanan kesehatan dan pendidikan, perluasan kesempatan kerja, pemberian dana bergulir melalui sistem kredit, dan pembangunan prasarana, masih berorentasi material dan belum menyentuh aspek atitude atau sikap dari orang miskin. Bahkan berbagai program yang ada pun belum secara optimal melibatkan dan mengembangkan potensi serta kapasitas yang sebenarnya telah ada dan dimiliki oleh masyarakat miskin itu sendiri.

Akibatnya, keberlanjutan upaya penanggulangan kemiskinan yang selama ini telah dilakukan sangat tergantung pada ketersediaan anggaran dan sangat bergantung pada komitmen pemerintah sebagai pelaksana program penanggungalan kemiskinan. Adapun masyarakat miskin yang selayaknya diperlakukan sebagai subjek dalam upaya penanggulangan kemiskinan, pada pelaksanaannya masih diperlakukan sebagai objek sehingga rasa memiliki dan komitmen terhadap program tidak terbentuk.

\section{B. KOMPETENSI LOKAL}

Berbicara mengenai konsep kompetensi, khususnya kompetensi lokal, referensi yang berkaitan dengan definisi kompetensi adalah:

1. A competency refer to an individual's demonstrated knowledge, skills or abilities (KSA's) performe to a specific standard. Competencies are observable, behavioral acts that requare a combinataion of KSAs to execute. They are demonstrated in a job context an as such, are influenced by an organization's culture and work environment. In other words, competencies consist of a combination of knowledge, skill, and abilities that are necessary in order to perform a major task of function in the work setting (JGN Consulting, Denver, USA).

2. Competency comprises knowledge and skills and the consistent application of 
that knowledge and skills to the standard of performance required in employment (Competency Standart Body, Canberra 1994).

3. Competency models that identify the skills, knowledge, and characteristics needed to perform a job ... (A.D. Lucia $\&$ R. Lepsinger/Preface xiii).

Dari ketiga definisi di atas dapat dirumuskan bahwa kompetensi diartikan sebagai kemampuan seseorang yang dapat terobservasi mencakup atas pengetahuan, keterampilan dan sikap dalam menyelesaikan suatu pekerjaan atau tugas sesuai dengan standar performance (kemampuan kerja) yang ditetapkan dan menjadi kekhasan suatu daerah tersebut.

Contoh nyata sebuah kompetensi lokal yang sudah diketahui oleh banyak orang dan identik dengan suatu daerah, antara lain ketika orang berbicara tentang Tasik, secara umum orang akan tahu bahwa kompetensi lokal masyarakat daerah Tasik adalah menganyam mendong. Begitu juga daerah Panjalu di Ciamis yang identik dengan kompetensi lokal berupa las besi, daerah Rajagaluh di Majalengka dengan membuat anyaman bambu, Garut dengan pembuatan dodol dan Majalaya dengan kawasan industri sandangnya.

Dengan demikian, rumusan kompetensi lokal tidak dapat dilepaskan dari dua sisi kajian. Satu sisi ketika berbicara kompetensi lokal dikaitkan dengan konteks yang dapat diterima oleh suatu entitas sosialprofesional atau "pasar", sehingga dapat diacu sebagai ukuran tingkat keahlian dalam bidangnya. Di sisi lainnya terdapat tarikan substansi (kebudayaan) yang kompleks, sebagai suatu jalinan multisektor, multidimensi, dan dinamis. "Kesepakatan" hanyalah dapat dicapai melalui kompromi di antara kedua sisi tersebut, bukan oleh penerapan semena-mena untuk mengalahkan atau memenangkan satu kutub dari kutub yang lainnya. Jika rumusan kompetensi memenangkan yang pertama (standar), maka ia akan lepas dari substansinya, misalnya menjadi sesuatu yang tak relevan lagi. Sebaliknya, jika yang pertama mengalahkan yang kedua (blur, fluid, dan local-specific), maka ia tak akan kesulitan dalam negosiasi dengan pasar umum, yang mempunyai tuntutan terhadap kompetensi ini.

\section{KOMPETENSI LOKAL DALAM MENANGGULANGI KEMISKINAN DI DAERAH INDUSTRI (KECAMATAN MAJALAYA KABUPATEN BANDUNG)}

Kecamatan Majalaya merupakan salah satu daerah industri di Jawa Barat yang masyarakatnya sejak abad ke-18 memiliki keterikatan yang sangat erat dengan kegiatan industri, khususnya industri sandang sehingga masyarakatnya bermata pencaharian dalam bidang ini atau bidang lain yang terkait dengannya. Hal ini antara lain membuat masyarakat Kecamatan Majalaya mempunyai kompetensi lokal yang khas.

Kompetensi lokal setidaknya dibangun oleh pengetahuan, sikap, dan keterampilan individu-individu dalam sebuah masyarakat untuk melakukan sesuatu. Kompetensi ini dibangun bersama melalui berbagai dinamika. Secara historis, ada pewarisan tradisi masyarakat oleh para agen sosialisasi kepada individu-individu anggota masyarakat. Dalam proses ini terjadi pewarisan kompetensi kepada generasi-generasi baru dalam masyarakat. Kompetensi yang diwariskan tersebut kemudian mengalami obyektivikasi sehingga menjadi milik bersama. Ketika hal itu terjadi, apa yang diwariskan tersebut menemukan beragam kenyataan yang mengharuskannya berubah atau bahkan ditinggalkan.

Sebagai contoh, kemampuan mengoperasikan mesin tenun tradisional ternyata kemudian tidak relevan akibat proses modernisasi mesin pabrik-pabrik tekstil di Majalaya, dengan demikian kompetensi lokal masyarakat Majalaya bukanlah sesuatu yang homogen. Kompetensi ini bersifat heterogen seiring dengan dinamika kehidupan yang dialami masyarakatnya. Heterogenitas ini tidak bisa dilepaskan dari kekhasan wilayah Majalaya yang secara historis dan sosiopolitik merupakan kawasan industri. 
Kompetensi lokal yang dimiliki masyarakat Majalaya mestinya menjadi modal yang kuat bagi upaya membangun kehidupan yang sejahtera. Namun faktanya, angka kemiskinan di Kecamatan Majalaya masih tinggi. Hal ini terjadi karena ada banyak faktor yang menyebabkan kurang optimalnya kontribusi kompetensi lokal bagi upaya penanggulangan kemiskinan di Kecamatan Majalaya. Kompleksitas dari masalah tersebut digambarkan dalam bagan berikut:

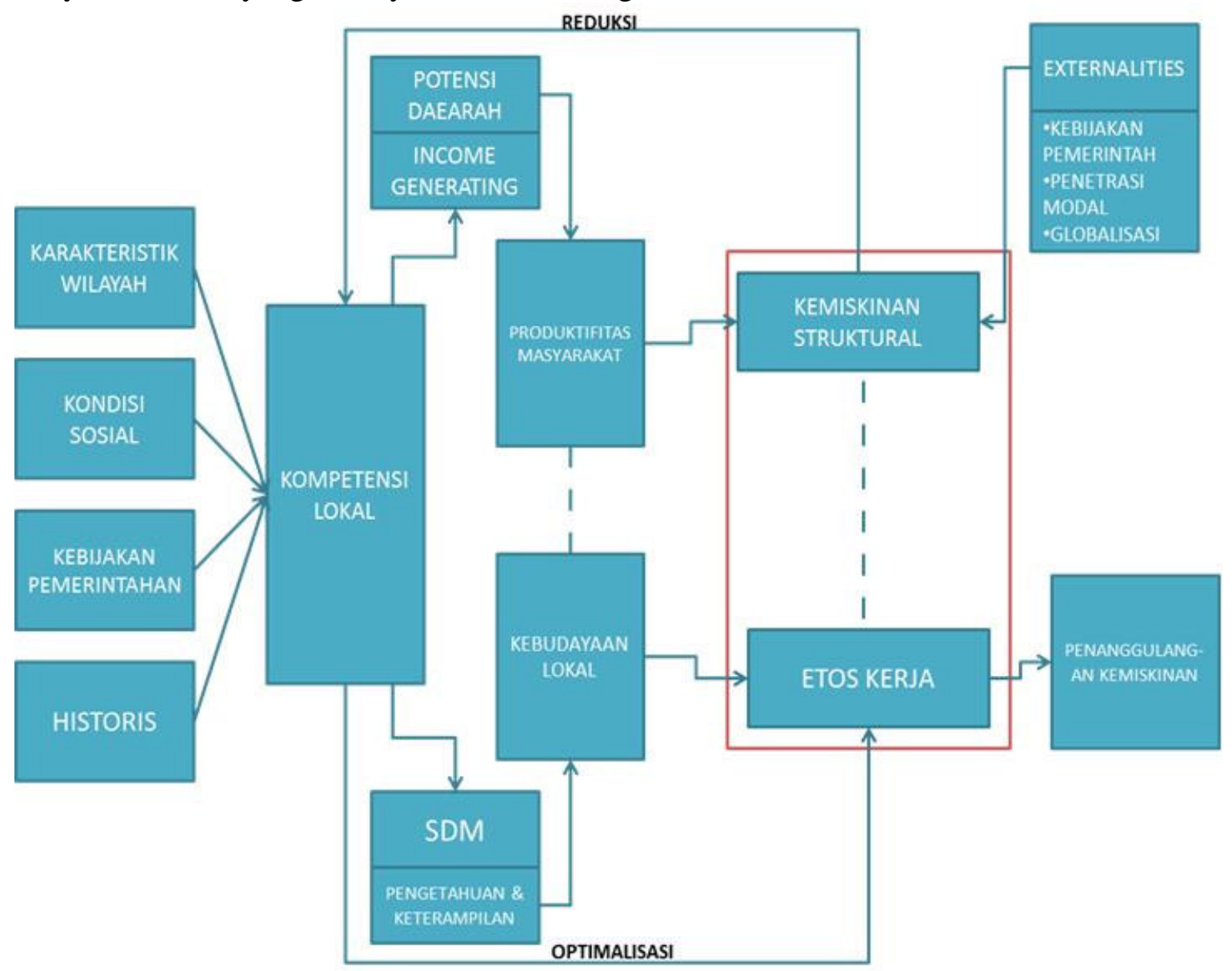

Bagan 1

Peta Konsep Kontribusi Kompetensi Lokal terhadap Upaya Penanggulangan Kemiskinan di Kecamatan Majalaya 
Dari bagan di atas, tampak bahwa karakteristik wilayah, kondisi sosial, kebijakan pemerintah, dan perjalanan sejarah membentuk kompetensi lokal yang bisa digunakan untuk mengolah potensi daerah sehingga menghasilkan pemasukan (income generating). Proses ini mestinya membangun produktivitas masyarakat. Namun terdapat faktor-faktor eksternal berupa kebijakan pemerintah, penetrasi modal, dan globalisasi yang menghambat berkembangnya produktivitas masyarakat sehingga timbul kemiskinan struktural. Sementara itu di sisi lain, dalam kompetensi lokal terjadi transfer dan pengembangan pengetahuan dan keterampilan sehingga membangun etos kerja. Pada kondisi ini, kemiskinan harus direduksi dan kompetensi lokal harus dioptimalkan sehingga kemiskinan dapat ditanggulangi.

\section{PENUTUP}

$\begin{array}{lcc}\text { Setiap } & \text { masyarakat } & \text { memiliki } \\ \text { kompetensinya } & \text { masing-masing } & \text { sehingga } \\ \text { muncul kekhasan } & \text { sesuai dengan } & \text { lokalitas }\end{array}$ masyarakat tersebut berada, yang secara alamiah kompetensi lokal tersebut tumbuh dan berkembang sejalan dengan upaya pemenuhan kebutuhan hidup masyarakat dan tidak dapat pula dilepaskan dari perubahan sosial yang terjadi di dalam masyarakat.

Kompetensi lokal yang dimiliki oleh masyarakat dibentuk, tumbuh dan berkembang seiring dengan pertumbuhan dan perkembangan kondisi geografis, historis dan sosio-politis wilayah sehingga pemerintah sebagai pemegang kebijakan dan sebagai unsur perencana pembangunan memegang peranan penting dalam upaya pengembangan kompetensi lokal suatu wilayah serta kompetensi lokal pun dapat berkontribusi positif dalam upaya penanggulangan kemiskinan.

\section{E. SUMBER BACAAN}

Buku, Jurnal dan Penelitian

Budimanta, Arif. 2003. "Prinsip-prinsip Community Development" dalam Akses Peran Serta Masyarakat. Jakarta: Sinar Harapan dan Indonesia Center for Sustainable Development.

Departemen Perindustrian, Direktorat Jenderal Industri Kecil dan Menengah. 2007. Kajian Pengembangan Kompetensi Inti Daerah. Bandung: PT. Multi Area Conindo.

Erickson, Thomas and Wendy A. Kellogg. 2000. "Social Translucence: an Approach to Designing Systems that Support Social Process" in ACM Transaction on Computer-Human Interaction, Vol 7, No.1.

Glen, Andrew. 1993. "Methods and Themes in Community Practice" in Butcher, H., et.all (eds)., Community and Public Policy, London: Pluto.

Manning, Chris dan Tajudin Tukiran. 1990. Struktur Pekerjaan Sektor Informal dan Kemiskinan di Kota (Sebuah Sudi Kasus di Diroprajan Yogyakarta). Yogyakarta: UGM Press.

Sahdan, Gregorius. 2005. Menanggulangi Kemiskinan Desa. Artikel Ekonomi Rakyat dan Kemiskinan. Jurnal Ekonomi Rakyat.

Suharto, Edi. 2005. Membangun Masyarakat Memberdayakan Rakyat. Bandung: Refika Aditama.

Supriatna, Tjahja. 1997. Birokrasi, Pemberdayaan, dan Pengentasan Kemiskinan. Bandung: Humaniora Utama Press. 
Dokumen, Media Massa, Blog dan Website

Bahua, Mohamad Ikbal. 2008. Pemberdayaan dalam Makna Kemiskinan. Bahua Ikbal Kreatif Blogspot.

Chaniago, Andrinof A. Kompetisi, Kompetensi dan Pembangunan Daerah. Suara Pembaruan, 26 November 2002.
Setiarso, Bambang. Pendekatan "Knowledge - Base Economy" untuk Pengembangan Masyarakat. www.Ilmukomputer.com.

$\underline{\text { www.desentralisasi.net }}$

Www.kompas.com 